\title{
RIGTINGLYNE VIR DIE KATEGESE VOLGENS DIE SINODE VAN DORDRECHT.
}

\author{
DR. D. W. DE VILLIERS
}

Dit is gepas om in 1968-1969, presies 350 jaar na die byeenkoms van die Gereformeerde ekumeniese Sinode te Dordrecht, aan. dag aan die verloop en die betekenis daarvan te gee. Die algemene indruk is dat die Sinode van Dord dor was omdat die leerstellige aspek sterk navore gekom het. Wie die gedagte en indruk daarop nahou, begaan 'n groot fout. Inteendeel. Dit was 'n Sinode vol gelaai met ekumeniese warmte; wat getuig van intense studie van die Skrifwaarhede en wat in die teken van gesprek en gedagtewisseling gestaan het. Dit sal ons goed doen om ook wat sy eku. meniese gehalte betref die bakens van die Sinode van Dordrecht weer in die oog te kry.

Wanneer die "here prinse van die kerk” - om A. G. Visser aan te haal - vir nagenoeg vyf maande bymekaar kom, dan moet die sake op die sakelys van gewigtige aard wees. Aan gewigtigheid, deeglikheid en rigtinggewende krag het dit nie ontbreek nie.

Die Sinode het nie onmiddellik begin met die groot saak in verband met die dwaling van die Remonstrante nie. Op 13 Novem. ber 1618 het die Sinode plegtig geopen - en dit was besonder plegtig ook gesien die feit dat Latyn gebruik is - met toesprake deur die hoogwaardigheids-bekleders. Hierna is die moderamen gekies, die eerste openbare leerrede gelewer en die werkswyse bepaal. Die buitelanders is op hartlike wyse verwelkom.

Die eerste belangrike saak wat die aandag gevra het, was die Bybelvertaling. Daarna het die onderwysing uit die Kategismus, die doop van heidense kinders wat in Christelike huise opgeneem is, die onderrig van proponente en die gebruikmaking van die boek. drukkuns, gevolg.

Reeds op 27 November kom die kategetiese onderwys aan die beurt. Drie volle dae is daaraan gewy. Die Sinode het ten opsigte van sy werksmetode reeds in baken geplant vir alle Sinodes en ook ten opsigte van die metodiek van die kategetiese onderrig. Die Sinode is naamlik in "colleges" verdeel. Daar was altesaam 18 sulke groepe. Hulle werkswyse is soos volg beskryf: "Deze colleges vergaderden afsonderlijk, behandelden elk voor zich het onderwerp, dat den volgende dag in discussie kwam en leverden 
desgewenscht elk een judicium of sententie in, tenzij iemand in het college hoofdelijk zijn stem wilde uitbrengen." By die algemene vergadering is die verskillende adviese voorgelê.

1.

By 'n nader studie van die verloop van sake, blyk dit dat die vaders van die Sinode die kategismuspreek in nou verband met die kategetiese onderrig gesien het. Kategismusprediking en kategetiese onderwys is saam bespreek. Die kategetiese onderwys het destyds op tweërlei wyse plaasgevind. Die kategismuspreek is beskou as die eerste metode van „eenvoudige“ onderrig. Die katkisant moes vooraf die vrae en die antwoorde opsê ten aanhore van die gemeente en daarna het die prediking uit die Kategismus gevolg. Die metode was dus meer induktief van aard. Soms is die vrae nie net aan die kinders gestel nie, maar ook aan die „bejaardes". Opvallend is dat dit noot in die oggend geskied het nie, maar wel in die namiddag. Die rede waarom die Friese en Overijelsse Kerke die gravamen ingedien het, was om besluite te kry wat die leraars verplig om dit met meer getrouheid en stiptelikheid na te kom. Saam is dan ook gesoek na die redes vir die verval en die volgende is aangedui:

1.1. Die nalatigheid van die leraar self.

1.2. Die feit dat gemeentes in kombinasie is en dit moeilik is om by beide die middag ' $n$ diens te hou:

1.3. Mense kom moeilik op 'n Sondagmiddag na die kerk.

1.4. Die Remonstrante het meegewerk tot die verval daarvan.

1.5. Die laksheid van die owerheid omdat hulle Sondagarbeid nie verbied nie.

Dit is ook duidelik dat die Roomse Katolieke Kerk in Friesland meer aandag aan kategetiese onderrig begin gee het en dat die enigste verweer teen hulle pogings die opknapping van die ou Gereformeerde praktyk geëis het. In sy Letters het Hales (Josephus Hall) die volgende betekenisvolle sin geskryf: „That here was now greater necessity than ever of reviving this custom, because the Jesuits who mightily labour in this kind, as appeared by some of their acts lately in Frisia."

Op die buitengewone katkisasie is verder diegene toegelaat wat wens om tot die nagmaal toe te tree. Dit is uitsluitlik deur katkisante bygewoon en het gewoonlik enkele maande geduur.

By verskillende geleenthede is die betrekking tussen kategetiese of kategismusonderrig en die Nagmaal vasgelê. Dit is steeds as ' $n$ toelating tot die Nagmaalstafel gesien. Verder is dit noodsaaklik beskou dat die lidmaat elke keer voor die Nagmaal opnuut 
'n soort onderrig sal ondergaan waardeur hy gehelp sal word om voorbereid na die nagmaal te gaan. So het die voortgesette karakter van die kategetiese onderrig tot sy reg gekom en is die ouderling intiem daarby geskakel.

2.

Die Sinode het weereens bevestig dat die inhoud van die Heidelbergse Kategismus die sentrale leerstof by die kategetiese onderrig was. Reeds in 1566 het Pieter Gabriel elke Sondagmiddag uit die Kategismus onderrig. Die Sinodes van Wesel (1568), Emden (1571) en die provinsiale Sinode van Dordrecht (1571) het duidelike uitsprake oor die gebruik van die Kategismus gedoen, alhoewel daar weinig oor die kategismusprediking as sodanig besluit is. Die Haagse Sinode van 1586 het egter bepaal dat die leraars op Sondagmiddae die predikasie moes hou deur die „Somma der Christelijke Leere inden Catechismo vervatet". Die predikant-kategeet het sy plek gewoonlik voor die preekstoel ingeneem sodat dit meer die vorm van 'n leerdiens of onderrigtende diens aangeneem het. Die besluit van die Haagse Sinode is dan ook herbevestig by die algemene Sinode van Dordrecht.

Die besluite van die Sinode in die verband was die volgende:

2.1. Dat die H.K. eenkeer per jaar in geheel behandel moes word.

2.2. Dat preke kort en bevatlik moes wees.

2.3. Dat die leraars en die ouderlinge die gemeente moet opwek om die prediking getrou by te woon.

2.4. Dat die kerkvolk hulle op Sondae nie moes laat verlei tot arbeid en sport nie en dat die owerheid versoek word om met strenge wette alle verleidinge en afleidinge te verbied.

2.5. Dat die owerhede versoek word om kombinasie-gemeen. tes op te hef, omdat dit moeilik is om om die beurt aan die kategismusprediking aandag te gee.

2.6. Dat die visitatore sal toesien dat die besluit van die Sino. de uitgevoer word.

Maar nou is dit opvallend dat die Remonstrante juis die prediking uit die Kategismus teengestaan het. Waarom het hulle gepleit vir 'n leerboek waarin slegs Skriftekse genoem word? Dit is duidelik dat die Remonstrante niks wou goedkeur wat kon help met die binding aan die leer nie. Hulle benadering was dus nie in die eerste plek omdat hulle so sterk vir die Bybel gevoel het nie, maar omdat hulle daardeur 'n geleentheid wou aangryp om hulle eie uitleg van die Skrif weer te gee, sonder binding aan die Leer van die Kerk. 
Die Sinode het hierdie fyn set van die Remonstrante deurgesien en hulle nie in 'n strik laat vang nie.

Dit is jammer dat alhoewel die H.K. tot leerboek verhef is, die Sinode juis ook die moontlikheid daargestel her vir die gebruikmaking van ander handboekies en vereenvoudiging van die Kategismus. Die A.B.C.-boekies en die Kort Begrip was reeds in gebruik en die gevoel is uitgespreek dat eenvoudige handboeke nodig was. Alhoewel die Sinode op sy 148-ste sitting besluit het dat die H.K. ten volle geskik is vir die onderwys aan die oueres en die jongeres, het die besluit ook geval dat die Kort Begrip van Faukelius - wat self ook lid van die Sinode was - „recommendabel“" is. Hiermee het dit sy algemene intog gekry en reeds in 1627 was dit in die psalmboeke van destyds opgeneem.

Die Sinode van Dordrecht het die taak van die drie organe of vennote in die onderrig van die onmondige gemeente in noue verband gesien. Die invloed van Calvyn in hierdie verband kan duidelik gèsien word. Dit neem nie weg nie dat eerstens die Dienaar van die Woord a parte Dei met outoriteit beklee was om as kategeet op te tree. Hy moes nie net self die onderrig waarneem nie, maar hy was 'n soort inspekteur van skole en gesinne om toe te sien dat die werk behoorlik uitgevoer word.

Dit is egter ook waar dat die Sinode van Dordt die plek van die ouer en die onderwyser op skool nie miskien het nie. Calvyn word verwyt dat hy die kategese te sterk na die huis en die skool verskuif het, 'n verwyt wat ten onregte aan hom toegeswaai word. Calvyn het dit reg gesien: in die uitvoering van die taak tree die kerk, skool en huis as drie vennote op. Die leraar, onderwyser en ouer staan in 'n intieme vennootskap. Die gevaar was toe dat die huiskatkisasie te hooi en te gras opgeneem is en die Sinode van Dordrecht het hom hieroor sterk uitgespreek.

Die afgevaardigdes van Hesse was van mening dat die ouers kategetiese onderwys moes ontvang met die oog op die doop. Die Switserse afgevaardigdes het reeds 'n soort van huwelikskatkisasie geken en Hales was van mening dat dit sou voorkom dat die paartjies te gou en te haastig trou. Die Bremense afgevaardigdes was van mening dat die katkisasie - belydeniskatkisasie deur hulle genoem - ook ten huise moes geskied. Verder moes die owerheid ook help om toe te sien dat die kategetiese onderrig uigevoer word.

Dit blyk ook duidelik uit die besluite van die Sinode in verband met die wyse van katkiseer. 
3.1. Dit sal geskied deur ouers in hulle huise; skoolmeesters in die skole en die ampsdraers in die kerke.

3.2. Naas die plig van die kerk het die owerheid ook ' $n$ verantwoordelikheid. Hulle is gevra om nie skole toe te laat waar nie deeglike onderrig gegee is in die kategismus nie.

3.3. Voortgesette onderrig is bepleit met die oog op die Nagmaal reeds drie tot vier weke voor die tyd.

4.

Die Sinode het ook benadruk dat daar rekening gehou moet word met die bevatlikheid van die katkisant. Die leerstof moet so ingedeel word dat dit verstaanbaar was vir die verskillende groepe. Juis hieruit het die behoefte gegroei om 'n kleinere kategismus daar te stel. Die Sinode het sover gegaan om ' $n$ kommissie te benoem bestaande uit die volgende: Polyander, Gomarus, Faukelius, Lydius, Udemannus en Thyssius. Hulle taak was aanvanklik om twee kleinere kategismusse daar te stel. Of dit geskied het, kan nie met sekerheid bepaal word nie. Dit skyn egter of daar teruggeval is op die Kort Begrip van Faukeluis.

Vir die kleinere kinders is die ses (vyf) hoofstukke van die Christelike religie en ook dele uit die Bybel genoegsaam geag; vir die meer gevorderde leerlinge is uttreksels uit die Heidelbergse Kategismus gebruik en die verkorte Kategismus van Palts of die Kort Begripvan Faukelius. Vir die oudste leerlinge in skool en in kerk is die Heidelberger aanbeveel. Die Waalse kerke kon die Geneefse Kategismus gebruik. Al die ander boekies is verbied. Die indelingsbeginsel van ouderdom is algemeen gevolg.

Volgens verskillende adviese is ook bepleit dat al die leerboeke van die Jesuiete uit die skole geweer moes word. Die Remonstrante het gepleit vir direkte onderrig uit die Skrif en wou ook nie weet van 'n kategismusmisbespreking sonder ' $n$ teks nie.

Verslag is ook gedoen ten opsigte van die onderwysende metode. Die gebruik om in die kerk die antwoorde hardop te sê was algemeen in swang. Die predikante moes ook kontrole uitoefen of die kinders onderrig is in die skole en hulle moes die kinders daar ondervra. Sommige het die Kategismus in geheel van buite geleer. Die onderwysers moes ook belyers van die Christelike godsdiens gewees het.

Adriaan Jorrissen Smout was nie lid van die Sinode nie, maar sy advies het skriftelik voor die Sinode gedien. Hales verwys na hom in sy Letters: „Adriaan Smouties had written a little book in 
the Belgick Tongue unto the Synod." Hy benader die hele kategetiese onderrig soos volg:

4.1. Na aanleiding van 2 Tim. 1:13 deel hy die kategetiese stof in. Hy wil analitiese studie van die verskillende Bybelboeke maak en plek gee na die Kategismusstudie. Hy pleit ook vir die aanhaal van bewysplekke uit die Bybel.

4.2. Daar kan twee metodes wees van onderrig $\mathrm{nl}$. die wederkerige en die nie-wederkerige. Die eerste is die gespreks of diskussiemetode en die lesingmetode.

4.3. Die kategetiese onderwys moes primêr by die huis geskied, verder in die skole en in die kerk op wederkerige wyse vir almal wat daaraan wil meedoen en op nie-wederkerige wyse vir die kinders.

4.4. Op Sondae moes daar driekeer onderrig word. Gedurende die oggend op eenvoudige wyse en tweekeer gedurende die middag. By die eerste geleentheid gedurende die middag net uit die ses hoofstukke van die Christelike religie en by die tweede geleentheid uit die kategismus. Gedurende die week moet privaat aan huise onderrig word met die oog op die Nagmaal.

Verder het die vier professore aanbeveel dat daar by elke ondervraging minstens een ouderling teenwoordig moes wees. Die Sinode het ook gewaarsku teen die gebruik dat leerstukke net bloot uit die hoof geleer word.

Interessant dat die gedagte van beloning van leerlinge ook genoem is en dat die onwilliges 'n geldboete opgelê moes word. Onwillige ouers moes ook deur middel van kerklike dissipline tot orde geroep word.

5.

Wanneer ons nou by 'n beoordeling van die Sinode van Dor drecht ten opsigte van die kategese kom, is dit ook nodig om die rigtinglyne deur te trek tot die praktyk van ons eie stand van sake vandag. Graag wil ons die invloed van die Sinode na aanleiding van enkele samevattings benadruk.

5.1. Die kategismuspreek is deur die Sinode gesien as onderrigtende werksaamheid van die kerk. Dit is steeds by 'n leerdiens gehou. Dit het gehelp om die lidmate te vorm om beter begrip van die waarhede van Gods Woord te kry. Dit was vir ouer en kind in die kerk. Daarom is daar steeds rekening gehou met die bevatlikheid van die kind self. 
Dit kom voor asof die kategismuspreek verkeerdelik te veel ' $n$ preek karakter gekry het en te min leeronderrig bevat. Gereformeerd besien leer ons uit die kategismus en preek ons oor ' $n$ teks. Die kategismuspreek hoe noodsaaklik en onmisbaar ookal, mag nooit die preek in die erediens op 'n Sondagoggend vervang nie. Ek sou graag wou sien dat ons iets meer hiervan moet terugkry $\mathrm{nl}$. dat die Sondagmiddag of aanddiens gewy word aan hierdie soort leerdiens waarby die katkisant, kind en ouer betrek word.

5.2. Die sentraliteit van die Heidelbergse Kategismus mag nie ondermyn word nie. Ons is Gereformeerd daarmee gevoed en het daarmee saamgegroei. Dit gaan in die onderrig in die Bybel maar ook oor die belydenisskrifte. Die rede waarom die Heidelbergse Kategismus voorrang gekry het, moet gesoek word in die feit dat dit primêr as leerboek opgestel is. Dit behels nie dat die ander belydenisskrifte nie tot hulle reg moet kom nie, inteendeel ek wil pleit vir gebruikmaking van aldrie formuliere van enigheid. Daarmee wil ek my egter verset teen enige poging om ander vraeboeke in te voer. Maar weereens bepleit ek, juis omdat die gedagte so sterk navore gekom het by Dordrecht, dat die Heidelbergse Kategismus en ook die ander belydenisskrifte opgestel moet wees in 'n taal wat ook verstaanbaar is vir die kleinere kinders.

5.3. Die juiste term vir alle onderrig in die kerk, is kategetiese onderrig. Die tyd het aangebreek dat die term „.Sondagskool" finaal uit ons taalgebruik geweer moet word. Die kerk is nie besig met 'n skool op Sondag nie. Die kerk is besig met onderrig aan sy onmondige lidmate, asook diegene wat daarom begeer. Ons moet liewers spreek van verskillende soorte kategetiese onderwys. Die klag van die Sinode van Dordt naamlik dat die werk in baie gemeentes afgeskeep word, is ' $n$ klag wat helaas vandag nog herhaal moet word. In 'n mate was $W$. van Brakel reg toe hy verklaar het: „,want het volck is doorgaans onwetende ende bloeiende predicatien zijn niet bequaam om de onwetende de eerste beginselen van waarheyt ende Godsaligheyt in te planten ...."

5.4. Die intieme band tussen kerk, skool en huis ten opsigte van die onderrig aan die kind, kan nie genoeg benadruk word nie. In engere sin praat ons nie meer van die kategetiese onderrig van die huis en die skool nie, maar ook dit is ' $n$ afwyking van die betekenis wat Dordrecht daar- 
aan toegeskryf het. Die verbondsgedagte kom by Calvyn sterker navore as by die Sinode van Dordt (i.v.m. die kategetiese onderrig), maar Dordt aanvaar dit as venselfsprekend dat die verbondsouer primêr verantwoordelik is en dat die skool hier 'n onmisbare taak te verrig het. So was dit aan die Kaap en nog 'n eeu daarna. P. B. Borcherds vertel hoe hulle Woensdae en Saterdae dele van die Kategismus moes opsê in die klas van mnr. George Knoop. Die vervreemding in die vennootskap van kerk, skool en huis; van leraar, onderwyser en ouer word te veel as vanselfsprekend aanvaar. Die veragtering in hierdie verband is nie in lyn met die historiese herkoms en begingeskiedenis in ons eie land nie. Die skool kan en mag nie neutraal staan nie en die verantwoordelikheid van die Kerk ten opsigte van die ouer mag nie vergeet word nie. Die Kerk moet help met die vorming van die ouer om sy taak in die huis beter te kan uitvoer.

Dit is my eerlike oortuiging dat ons die gesin te veel sien as ' $n$ instrument vir die gemeente en sy aktiwiteite en te weinig besin oor hoe die kerk die gesin kan dien om sy taak in die koninkryk van God meer effektief te kan uitvoer.

5.5. Die Sinode van Dordrecht gee 'n senrale plek aan die kategetiese onderrig in die werksprogram van die predikant. Tot vandag toe staan dit nie alleen in die beroepsbrief, as plig van die predikant nie, maar dit is 'n taak waarvoor hy saam met die kerkraad verantwoordelik is. Juis in ons tyd behoort aan hom meer tyd gegun te word om hierdie taak beter te kan uitvoer. Ons taak is nie net om te verkondig nie, maar ook om te leer.

5.6. Dit is van geen geringe betekenis dat die drie groot sake op die sakelys van die Sinode van Dordrecht juis leersuiwerheid, Bybelvertaling en kategismusprediking en onderrig was. Hierdie drie sake is vir die Gereformeerdes van alle tye van kardinale belang. Die Hervorming het nie net vir ons die Woord teruggegee nie, maar wou opnuut die lidmaat van die gemeente help om dit beter te verstaan in die lig van die belydenis en deur voortdurende onderrig in die kerk. Die lidmaat moes leer om die Bybel self te hanteer en self te verstaan.

5.7. Die Sinode van Dordrecht was in 1618-19, die Statevertaling is in 1637 oorhandig en pas 33 jaar en 15 jaar onderskeidelik daarna, het Jan van Riebeeck aan die Kaap aan wal gestap. Daarom was dit dan ook so dat die patroon 
van ons eerste kategetiese onderwys aan die Kaap die uitvloeisel van die besluite van Dordt was. Ook by ons het die leerboeke, die leermetodes en manier van katkiseer inslag gekry. Die Sinode van Dordrecht staan veel nader aan ons eie geskiedenis as wat ons dikwels daaraan toeken.

R. Bijlsma het in sy Kleine Catechetiek 'n treffende samevatting gegee van die „lijnen“ wat aangegee kan word ten opsigte van die vernuwing van die kategese soos deur die Reformasie bewerkstellig.

1. Die skriftuurlike uitgangspunt het meegebring dat die Bybel weereens sentraal te staan gekom het.

2. Die nadruk van die priesterskap van die gelowige het daartoe gelei dat teologiese kennis ten deel van die hele volk behoort te wees.

3. Hieruit het ook gevolg dat die persoonlike verstaan en die verwerking van die leer die aandag gekry het.

Hy slaag verder daarin om aan te toon dat hierdie Reformatoriese lyn in die besluite van die Sinode van Dordrecht voortgesit is. Samevattend wil ek graag sy beknopte beskouing van die betekenis van die Sinode vir die kategetiese onderrig hier weergee:

1. „Geregelde zondagse cathismusprediking. Deze preken moesten „behoorlic cort” zijn en te begrijpen voor kinderen.

2. Cathechetisch onderricht door de schoolmeesters op de scholen tweemaal per week; voor de kleintjes kon worden volstaan met de tekst van het Apostolicum, de Tien Geboden en het Onze Vader en iets over de sacramenten met enkele korte gebeden, wat eenvoudige vragen over de drie delen van de Heidelberger en enige bijbelteksen: voor de iets gevorderden werd een uittreksel uit de Heidelberger aanbevolen; en voor de grotere kinderen de volledige $\mathrm{Hei}-$ delberger.

3. Catechistasies door predikanten, ouderlingen of krankenbezoekers, zowel voor de jeugd als voor volwassenen.

4. Het gezinsondericht thuis. De ouders moesten hun kinderen gewennen aan de huislijke gebeden, het lezen van de Heilige Schrift met verklarende toelichting en zij moesten hun de catechesmus overhoren. Nalatige ouders zouden vermaand of zelfs gecensureerd dienen worden. 
Het ,,terug tot de bron van de klassieke oudheid" in de humanistiche Renaissance vond een minstens even belangrijke pendant in het "terug naar de bron van de Bijbel" der reformatoriche Renaissance.

Op die historiese pad van die kategetiese onderrig, staan die Sinode van Dordrecht as baken, duidelik, hoog en geankerd.

Mag die Dordtse leerreëls wat as resultaat en vrug van die besinning van die Siode die lig gesien het, ook in hierdie feesjaar tot meerdere reg en bestudering ook in die kategetiese lokaal kom. 